\title{
El motivo del rey viejo en el Persiles de Miguel de Cervantes. Algunas observaciones a partir de Maximino y otros poderosos sustituidos
}

Recibido: 25/6/2020. Aceptado: 17/12/2020.

A la memoria de Gabriel, mi hermano mayor

\begin{abstract}
Resumen
Maximino aparece en las últimas páginas de la novela ante la basílica de San Pablo Extramuros. Ocupa poco espacio. Quizás por eso casi no ha recibido atención por parte de la crítica. Sin embargo, compone la figura del "rey" en su momento más difícil, el traspaso del poder.
\end{abstract}

Apoyado en el magnífico estudio de Kantorowicz, especialmente en las analogías político-teológicas del rex-sacerdos con el Corpus Christi-Corpus mysticum, mi trabajo hilvana reyes bíblicos e históricos, citados o evocados por la novela, hasta llegar a la concepción de realeza propuesta en las primeras páginas.

Así, desde el final hasta el principio, la imagen de Maximino toma "cuerpo" hasta convertirse en figura alegórica. San Pablo está en la raíz poética y teológica de esta historia centrada en el artificio.

\section{Palabras clave: Rey; Corpus mysticum; historia; teología; alegoría.}

\section{The Old King Motif in Cervantes' Persiles. Some Considerations on} Maximino and Other Displaced Powerful Figures

\footnotetext{
Abstract

Maximino appears in the final pages of the novel, at the Basilica of St Paul Outside the Walls. This character has received almost no critical attention, perhaps due to the fact that he plays such a small part in the story. Nevertheless, he represents the figure of the "king" at the hardest of times: the transfer of power.
} 
Based on Kantorowicz's remarkable study, especially regarding the political-theological analogies between the rex-sacerdos and the Corpus Christi-Corpus mysticum, my work interweaves biblical and historical kings cited or evoked throughout the text, to finally address the idea of royalty suggested in the first pages of the novel.

Thus, from the end to the beginning, the image of Maximino gains substance, ultimately becoming an allegorical figure. St Paul is the poetic and theological cornerstone of this story centered on artifice.

Keywords: King; Corpus mysticum; history; theology; allegory.

Recién en las páginas finales del Persiles se nos da a conocer el personaje de Maximino, quien, sin embargo, parece estar en el origen de las peripecias de los protagonistas. Como figura de un rey moribundo, el inicio y el final de la historia se encuentran condensados en el hermano mayor de Periandro/Persiles. El reconocimiento de este detalle invita a relevar las sugerencias del texto sobre figuras de padres y reyes en la historia fáctica, bíblica y mítica.

No bien asumidos los nombres verdaderos de los protagonistas, que los lectores conocíamos desde la portada del libro Los trabajos de Persiles y Sigismunda, se suceden dos escenas concatenadas que resuelven la apoteosis final de los protagonistas (IV, 13 y 14). El proceso de manifestación se ha cumplido.

La primera de las escenas, la crucifixión de Persiles (Parodi, 2018a), interpretación mediante, del episodio del reencuentro de Periandro por parte del ayo Serafido y el inesperado Rutilio, y la subsiguiente salutación, en que Serafido abraza por el cuello a Periandro y Rutilio rodea su cintura. Pirro, ardiendo en melancolía, por ver a su rival tan honrado, lo traspasa de hombro a hombro con la espada.

Adivinamos en el cuerpo de Periandro la vertical de una cruz, cuyo brazo transversal está dibujado por la espada del envidioso ofensor. Serafido y Rutilio sueltan el cuerpo, que cae en brazos de Auristela. Inmovilizada, incapaz hasta de llorar y suspirar, a su vez, deja caer la cabeza y los brazos a los lados del cuerpo (dejar caer los brazos es signo de decaimiento, como leemos en la Carta a los Hebreos 12,12). Auristela, enferma (II, 12), ya ha dado esa señal, cuando sufría de la enfermedad celosa. Pero aquí compone una Pietà. Crucifixión, Descendimiento y, por fin, Pietà (Réau, 1996). Así, pues, el sufrimiento se nos comunica por gestos y posiciones que acrecientan su efecto al repetir imágenes de un arte sacro particularmente elocuente.

Símbolo de símbolos, arte del arte. Agreguemos a Serafido y Rutilio como atributos de la crucifixión: Serafido encarna, en tanto ayo y no maestro ("mi hijo Persiles" lo llama en su relato (IV, 12, 701), el espíritu, tamizado por la meditación franciscana (puesto que el nombre recuerda al Seráfico San Francisco); Rutilio ciñe el cuerpo sacrificado para la salvación de todos.

Rostros desangrados, de apariencia cadavérica, contemplan la segura muerte de Periandro, mientras el violento recibe su castigo y la tentadora y sensual Hipólita, el perdón, en somero juicio.

Corte de capítulo: asistimos a otra escena de sangre y consternación. Sin embargo, el tremendismo cede ante la solemnidad de lo que podríamos llamar un ritual. Se suprime la opacidad de la sugerencia simbólica y la lectura de capas de representación artística. Ingresa en escena el moribundo Maximino, hermano mayor de Persiles, a quien el lector acaba de conocer por el largo relato de Serafido, y, allí, frontero al templo de San Pablo, en la campaña rasa, conduce una extraña ceremonia: la mano derecha toma la izquierda 
de su hermano y la dirige sobre sus ojos. La izquierda toma la derecha y la junta con la de Sigismunda. La sangre y los amigos están llamados a ser testigos del casamiento.

Con el último aliento, Maximino los llama "hermanos", pero también "hijos", y explica, como si se tratara de una liturgia, el significado de la ceremonia: casa a Persiles con Sigismunda, y lega a su hermano menor los dos reinos, el heredado de sus padres y el que hubiera recibido de Sigismunda. El matrimonio del heredero, la herencia y la muerte propia están previstos como simultáneos por el oficiante.

Según las pautas del género, la sucesión de los mitemas prueba final y apoteosis del héroe supone el casamiento con la princesa y asunción de la paternidad. El héroe, coronado como rey, ocupa el lugar del dimitente (Forcione, 1972: 106). Pero cada reedición del mito presenta sus particularidades. Lejos de la disminución (enfermedad, ridículo, inmoralidad) que padecen los reyes destituidos o dimitentes, muchas veces-como en este caso-hermanos mayores, la última escena nos revela un segundo sacrificio, una renuncia que redime al personaje del peor pecado de la novela: los celos. El agente redentor parece, sin embargo, la sangre de Persiles, invocada a la vez como testigo del matrimonio. Derramada en la escena de la crucifixión, baña la subsiguiente escena ritual.

Acorde con la teología paulina, "el varón es la cabeza de la mujer, como Cristo es la Cabeza y el Salvador de la Iglesia, que es su Cuerpo" (Efesios, 5, 27). El valor alegórico del casamiento consagrado frente a la basílica de San Pablo se vuelve indudable. ${ }^{1} \mathrm{Se}$ trata de un casamiento místico, del Uno con los muchos. En orden a la representación de esta pluralidad, aparecen, iluminados por la escritura del Apóstol, otros caracteres que hacen al orden jurídico.

Notemos primero que, si bien los dos protagonistas provienen de la gentilidad, Periandro parece ya bautizado. En cambio, Auristela demuestra más deficiencias en su adoctrinamiento en el cristianismo. Para ello debe aprender el Credo, y en una versión mucho más teológica que la que pronuncia la bárbara cristianizada Ricla (en I, 6). El Credo de Auristela (IV, 5) incluye, entre otras diferencias, el argumento judiciario de origen paulino, por el que sólo Cristo, humano y divino al mismo tiempo, tiene la dignidad suficiente como para reparar la desobediencia del hombre al Dios Creador. Si la novela incluye dos Credos, es porque está alegorizando con esta constitución un concepto político, asociado al del cuerpo místico. El Credo de Ricla, además, asegura, con su origen natural, la universalidad que retoma el de Auristela. ${ }^{2}$

La sucesión nos conduce a otro detalle paulino del perfil jurídico del rex sacerdos, la alteración de la sucesión. Maximino, como heredero de su padre, muerto recientemente, parece ejecutar un único gesto regio: coronar a su hermano. No le deja en herencia el mismo reino que le dejó su padre, sino el que hubiera heredado si se hubiera casado con Sigismunda. Si bien no hay un cambio de linaje, no deja de recordar a Melchisedec (Hebreos 7 que retoma Génesis 14). ${ }^{3}$ Su nombre, analiza Pablo, significa "rey de justicia" y, por ser rey de Salem, lo es de la paz. Rey y sacerdote al mismo tiempo, prefigura, por la novedad de su linaje, el sacerdocio de Cristo, que no pertenecía a la tribu sacerdotal de Leví, ni era sacerdote. ${ }^{4}$

\footnotetext{
1 Sobre la alegoría cervantina inspirada en San Pablo, alertó tempranamente el uruguayo Cecilio Peña (2020), lo mismo que la existencia de "franciscanismo" en la novela.

2 Ver Armstrong-Roche (2009: 85-86, 135-157) para la comparación de los dos credos, desde otra perspectiva crítica. 3 Sobre el rex sacerdos, mítico “rey del mundo”, ver Guénon: 1985.

4 Persiles es figura del sacerdocio de Cristo al "morir" en la Cruz; es también rey como Cristo, quien así fue enunciado por los profetas Samuel 7,1-17 y Zacarías 9, 9. Integra, por lo tanto, la serie de rex-sacerdos.
} 
Por fin, el cadáver. Como tantas otras veces, Cervantes usa como símbolo de la Iglesia, el coche. ${ }^{5}$ Mientras el cuerpo semi-vivo de Persiles es conducido al coche de Maximino, en señal de su sustitución del poder, el cuerpo muerto de Maximino es trasladado desde la campaña rasa a la basílica de San Pablo. Así, la "iglesia y templo magnífico, casi el mayor de Europa" se convierte en mausoleo real.

El cadáver, yacente frente a esta construcción eclesial, compone la primera analogía de Maximino. Resulta particularmente sugerente si pensamos que San Pablo Extramuros se levantó sobre la tumba del apóstol San Pablo. No encontramos, sin embargo, analogía entre esta reedición del mitema del rey viejo con san Pablo. Pero quizás, la imagen del par de hermanos, Persiles y Maximino, nos inclina a pensar en san Pedro como hermano. Ambos, Pedro y Pablo, fueron martirizados el mismo día, y por eso comparten la festividad que los conmemora. Es más, la Historia Eclesiástica de Eusebio de Cesarea cuenta que, en el siglo II, en época de persecuciones, se escondieron juntos los restos de los dos apóstoles.

Maximino cumple algunas funciones características de san Pedro, y, en realidad, de toda la clase sacerdotal, que derivan del mutuo reconocimiento entre Cristo y Pedro, según nos cuenta el evangelista Mateo. Dice Pedro a Jesús: "Tú eres el Mesías, el Hijo de Dios vivo"; Jesús entonces le confiere la potestad de regir la iglesia:

Tú eres Pedro, y sobre esta piedra edificaré mi Iglesia, y el poder de la Muerte no prevalecerá contra ella. Yo te daré las llaves del Reino de los Cielos. Todo lo que ates en la tierra, quedará atado en el cielo, y todo lo que desates en la tierra, quedará desatado en el cielo (Mateo 16, 18-19).

Heredero de esta atribución petrina, Maximino casa y corona a su hermano Persiles. Sobre la piedra de su cadáver, se erige la iglesia gentil que congregaron los viajes y cartas de san Pablo.

Volvamos ahora a la sangre del Crucificado que baña la escena del ritual. El detalle no debe pasar desapercibido. Parece decir que el valor del sacrificio único derrama en los gestos que hacen a la institucionalización de la comunidad en tiempos históricos. Se trata de una hipóstasis de la encarnación. La renuncia de las figuras regentes que hilvanan este trabajo -cuanto más históricas, más elocuentes-, participan así de las consecuencias revitalizantes de la sangre primera. Leyendo en sentido contrario al de la peregrinación, en las primeras páginas de la novela encontraremos el lenguaje críptico de una profecía, que augura una civilización originada en el sacrificio. No se habla de un cuerpo entero, sino apenas de un corazón. Las citas de Pablo, quien primero habló de alegoría en el ámbito bíblico (Gálatas 4, 24), iluminan este recorrido de lectura, que enmarcamos en una estética manierista. ${ }^{6}$

\section{La historia en la novela del rey}

Un sujeto plural, un sujeto histórico, un rey. Kantorowicz (1985: 19-33), en su tan iluminador estudio sobre el rex sacerdos, conecta esta concepción dual de la realeza a la doble naturaleza de Cristo, humana y divina a la vez. Con el correr del tiempo, en el

\footnotetext{
5 La mujer en coche, en el Quijote I, 8 en el episodio del vizcaíno; en II, 6o, la mujer viaja con una hija, en el de Roque Guinart. Para su interpretación alegórica, ver Parodi, 2017: 59 y 203.

6 Panofsky (1984: 91 y 92), explica el gusto por el simbolismo, las representaciones alegóricas o la emblemática de las representaciones manieristas como una respuesta a la disolución de la armonía del sujeto y objeto propia del Renacimiento: "Separado de la naturaleza, el espíritu del hombre se refugia en Dios, con un sentimiento de triunfo y a la vez de pobreza, que se refleja en las figuras y en las posturas, tristes y al mismo tiempo soberbias, de las representaciones manieristas en general, y del que la propia Contrarreforma no es más que una expresión más."
} 
siglo XIV, según su referencia al estudio del Cardenal Lubac, Bonifacio VIII comienza a hablar de corpus mysticum. Se transfiere así la idea del Corpus Christi eucarístico al colectivo humano, la Iglesia. Y de allí surge la rivalidad y contaminación entre la iglesia y el poder político, los celos entre el rey y el papa.

Sin entrar en verosimilitudes jurídicas e históricas, nos interesa para los propósitos intra-textuales del trabajo el uso novelístico de estas ideas al reeditar los mitemas del género. Si el príncipe Arnaldo compone el polo espiritualizante (en el libro III abandona a Auristela por honrar a su padre, en el duelo por su retrato del libro IV pierde poca sangre), veremos a Periandro avanzar en una progresiva encarnación. Nuestro propósito es dar cuenta de algunos signos de la isotopía historia, por la que el autor introduce una tonalidad realista (esto es, encarnada). Isotopía doble -historia espiritual e historia política-, cuyos accidentes resignifican el devenir novelesco.

En esta línea de análisis, elegimos reseñar las ocurrencias textuales de Carlos V, el único rey verdaderamente histórico que nombra la novela. Llamativamente, siempre se lo evoca desde un contexto francés. La primera cita lo muestra en guerra en Alemania contra el duque de Clèves (I, 5, 162). ${ }^{7}$ Quien evoca al César Carlo V es su súbdito, Antonio padre, ambos jóvenes en lejanas épocas. En la tercera cita, a continuación del estado ruinoso del padre de Arnaldo, se da la noticia de su muerte (gloriosa); en contraposición, se ofrece una imagen de la universalidad de su imperio: Carlos V, "rey de España y emperador romano, terror de los enemigos de la Iglesia, y asombro de los secuaces de Mahoma" (II, 21, 422-423). Parecida imagen, en el libro III: el "rayo espantoso de la guerra, jamás como se debe alabado" convive con el recuerdo de su ingreso en "la milicia divina" (III, 18, 603), esto es, el retiro en el Yuste, similar a la mención en II, 19, 414.

La imagen del retiro se asocia cómodamente a la del ermitaño, con una marcada repetición de motivos entre las ermitas del Libro II y III. Ambas escenas se nutren del conjunto de tópicos asociados al Beatusille y a la vida solitaria (Leuker, 2011), que subrayan la positividad del retiro. Pensamos en Horacio, en Petrarca, pensamos en el encarcelado y libre Fray Luis cuando leemos la alabanza a la paz de la vida campesina, la bondad de los alimentos sencillos, la acogida generosa, la libertad de los que han renunciado a las acechanzas de la vida en la polis. Tal expansión de tópicos de la literatura clásica y renacentista se suma a la coincidencia antes apuntada, Francia. En el Libro II, entrelazado con el final del relato de Periandro, los peregrinos encuentran refugio en las ermitas de los franceses Renato y Eusebia. En el Libro III, cuando pisan territorio francés, se encuentran con el ermitaño Soldino.

Los dos episodios suponen un hito en la novela: en el caso de Renato y Eusebia, personajes secundarios vuelven a sus países de origen. Uno, Rutilio, se queda como ermitaño en la isla de las ermitas, como faro purgativo de la peregrinación. El episodio de Soldino, en cambio, cierra la peregrinación francesa concentrando alusiones a diferentes tópicos diseminados en el libro III, y también en la novela entera. A su vez, ambas ermitas configuran hitos en la novelación de los tiempos del mito cristiano: la ermita y sus imágenes, representación de la unidad mística eclesial, se constituyen en refugio del peregrino, como lo fueron de la pareja de enamorados Renato y Eusebia; en cambio, la ermita del judiciario Soldino, a la salida del territorio francés, en la inminencia de la llegada a Roma, dramatiza un ata y desata que anticipa el Juicio Final.

7 Ver nota 12 de la página 162 en la edición de Romero Muñoz. Todas las citas del Persiles corresponden a esta edición. 


\subsection{Renato y Eusebia}

El final del Libro II se constituye en instancia refundacional. El rey francés no limpió la deshonra de la inmaculadísima Eusebia. El duelo no hizo justicia a los rivales. La rivalidad se tiñó de ribetes políticos, según el análisis de Armstrong-Roche (2009: 224-230). La reparación del daño parece explicarse mejor desde las imágenes que habitan la ermita. Ellas recuerdan el pasaje en que Cristo, desde la cruz, traspasa su filiación a Juan, el discípulo amado ("Mujer, he aquí a tu hijo"/"He aquí a tu madre", Juan, 19, 26-27). Debemos agregar que la representación supone el INRI: se trata de un rey, el de los judíos. El sacrificio de un rey-hijo hace posible la constitución de un cuerpo universal, según la carne y según la divinidad.

No es dato menor que, entrelazado con este episodio, termine el inexplicablemente largo relato de Periandro. Periandro, después del sueño con la castísima y evanescente Auristela, cuenta la doma del caballo del rey Cratilo. ${ }^{8}$ La alusión al diálogo platónico está a la vista. Y de hecho, el relato de Periandro se funde con la diégesis, como la palabra que se funde con la cosa. Es ineludible recordar las palabras del Evangelista Juan: "Al principio existía la palabra", "Y la palabra se hizo carne" (I, 1 y 1,4). La unidad de la palabra y la carne ilustra, en este final del Libro II, el pasaje de la esfera del Uno a la dimensión colectiva, esto es, el repetidamente mencionado casamiento paulino de Cristo con la Iglesia. A su vez, las imágenes de las ermitas, al final del Libro II, concentran la idea del Libro III, cuya última novelita, la de Isabela Castrucho nos habla del valor de la palabra mistérica como sacramento (Parodi, 2018b). La Encarnación del Verbo es el acontecimiento decisivo que mueve la construcción alegórica de la novela, desde la profecía bárbara hasta las escenas finales. ${ }^{?}$

Por eso, los tópicos clásicos parecen absorbidos en la universalidad de las verdades teológicas. De modo que el retiro de Carlos V puede asociarse al reencuentro de estas verdades. Aunque de incomparable condición social, Rutilio representa esa aspiración contemplativa en el curso novelesco: su nombre significa precisamente "iluminado" (Leuker, 2011). Purgará una vida "hasta entonces mala" (II, 21,424), lejos de las discordias humanas.

\subsection{Soldino}

A diferencia de Renato y Eusebia que aparecieron ante los peregrinos como dos estatuillas movibles, Soldino es una sola estatua, que también se mueve: así surge en la novela este personaje que parece construido a base de fragmentos mal soldados. Su función no es otra que la de recolectar los acontecimientos narrados y proyectarlos a un final tan ultraterreno como su ermita.

No es peregrino ni religioso; tampoco adivino; es judiciario, se define. Su estampa se asocia con la nieve o con una estatua, tal es la blancura. No parecía religioso, pero podría ser un...obispo: lleva báculo. Lo conocen, no solo en Francia, sino en todas las partes de la tierra.

Como juez, aparta a los malos de los buenos, a Bartolomé y la Talaverana del resto de los peregrinos, a los que salva del fuego. En alusión al Juicio final, seguramente, dice que no es la entrada sino la salida lo que hace a los hombres discretos. Una España expurgada pedía la profecía del abuelo del jadraque, en la Iglesia de ferradas puertas de Valencia que ampara a los peregrinos de la invasión mora (III, 11, 547-540 y 553559). En Francia, Soldino efectivamente expurga a la comitiva. 
Soldino guarda las puertas del paraíso de su ermita, pero ésta es una versión mística de la Iglesia erigida por Cristo sobre la piedra que es Pedro. Se trata de una cavidad profunda, como los paraísos subterráneos que nos ofrece la literatura fantástica, recopilados por Patch (1956): el otro mundo, con sus obligados locus amoenus o beatus Ille. Villegas nos ayuda a reconectar estas imágenes a la evocación de Pedro; dice que el apóstol es "piedra que tiene la propiedad de bajar hasta el centro" (1591: 210). Aunque al final del tramo francés, esta ermita, quintaesencia de la unión de lo humano y lo divino, por estar hecha por manos del propio Soldino, quizás aluda a las construcciones de Francisco de Asís, albañil de la Porciúncula (la 'Porcioncita'), ermita que reunió a sus primeros seguidores.

A diferencia del episodio de Renato y Eusebia, y a semejanza del episodio de la orilla valenciana, la ermita de Soldino, que anticipa el fin de los tiempos, repite el tópico de la profecía. Como la valenciana, es una profecía retrospectiva. Si la exhortación, en dos tiempos, al rey prudente, que el jadraque pone en boca de su abuelo pide una España "entera y maciza", una tarea por cumplir, la profecía de Soldino descansa en las brillantes imágenes del guerrero triunfante y del guerrero abatido. En una actualización del pasado en el futuro, Soldino ve al "mancebo de la casa de Austria", descabezar un pirata, bañar las medialunas de sus banderas, pelar las luengas colas de sus caballos. También ve a "otro coronado joven", tendido en la arena, atravesado por mil moras lanzas, "el uno nieto y el otro hijo del rayo espantoso de la guerra, jamás como se debe alabado Carlos V" (III, 18, 599). ${ }^{10}$ La imagen de Carlos V recibe así la proyección desde las gestas gloriosas -en la vida y en la muerte-de sus descendientes. La circularidad profética resulta una extraña manera de novelar la sucesión. Con esas imágenes bélicas de fondo, Soldino aprovecha para identificarse, él mismo, como soldado al servicio del rey.

Identificación prestigiosa a la que añade la demostración de poderes. Declara el verdadero vínculo de Periandro y Auristela, el futuro de Constanza, el de Croriano y Ruperta. Sin duda, lo podemos caracterizar como sabio. Según su orgulloso autorretrato es "señor de sí mismo" y dueño del conocimiento universal puesto que ha estudiado las matemáticas, el movimiento del sol y la luna; como el Eclesiastés, además, ha encontrado causas para alegrarse y para entristecerse. Uno en la tierra, todo queda soldado en la imagen que de sí da Soldino. Por eso nos sorprende una autodefinición, sin embargo, dual. Aunque se reconoce español, cree necesario justificar su vida en Francia: son tierras habitadas por gentes "católicas y santas".

El sabio habla del rey...que se vuelve sabio. ¿Se pueden transferir todos estos poderes al rey que meditó en el Yuste, habiendo traspasado la gloria guerrera, en la vida y en la muerte, a sus descendientes? Carlos $V$ instala en la novela la imagen de un rey dimitente, prestigiado aun desde sus descendientes.

Pero ahora, ¿extenderíamos estas analogías a Maximino? Maximino fue soldado valeroso como Carlos V, como Soldino. Pero cuando por única vez aparece en la escena novelesca, a las puertas de la basílica, se le ha escamoteado la gloria del poder. Su linaje simbólico se acerca más al apóstol que compartió el martirio con Pablo. Esto es, Pedro. Si bien Pedro es "Príncipe de los apóstoles", lo es en cuanto Vicario de Cristo, atestigua Villegas (1591: 210). Y no hay que olvidar que Pedro es también figura del pecador arrepentido (por eso, ornamento de confesonarios). A su imagen, Maximino depone su deseo, enmienda el error. Su cadáver lo convierte en testimonio de purgación, y por ello, de grandeza.

Pero, ¿por qué Francia para novelar esta síntesis de contrarios? 


\section{Francia y el corpus mysticum}

Francia le ofrece al narrador la posibilidad de connotar simultáneamente las dos historias que se conjugan en el corpus mysticum de la Iglesia. Por un lado, la historia espiritual, protagonizada por la espiritualidad franciscana. Por otro, la historia política. El vehículo de esta evocación, que contribuye a construir el significante historia y, con ello, dirigir la novela hacia una progresiva encarnación, son, casi siempre, los nombres.

La mujer que se tira desde la torre y con su falda dibuja el campanario de una iglesia se llama Claricia, como Santa Clara. Periandro, convertido en un Cristo Redentor, cae de ella envuelto en la misma sangre del enemigo. El segundo de san Francisco se llama Antonio, como san Antonio de Padua y Lisboa. Debemos decir que los sucesos ocurridos en Provenza son particularmente franciscanos porque a Francisco se lo llamó así, por el origen francés de su madre, y no Giovanni, su nombre de bautismo. También se lo llamó el Provenzal (la Flos de Villegas -1591: 339- y La leyenda áurea de Santiago de la Vorágine, 1995: 639-640, abundan en estas explicaciones). La confirmación del franciscanismo la obtenemos en Roma: como ya hemos comentado, a propósito de la crucifixión de Persiles, Serafido evoca el serafín que presentó el cuerpo crucificado de Cristo a Francisco, al tiempo que a éste se le abrían los estigmas en pies y manos. Mucho planto, mucha franciscana sangre en el tramo francés, que guarda connotaciones autobiográficas, ya que Cervantes murió como terciario franciscano.

Pueden verse otros trabajos sobre el franciscanismo del Libro III (Parodi, 2018a, 2018b). Para la historia política que se entreteje con esta y pisa, a veces, los mismos significantes, acudimos al trabajo de Pierre Nevoux (2016), que focaliza los capítulos 13-15 del libro III, en relación con otros lugares textuales. También analiza Nevoux el texto cervantino desde la sugestión que producen los nombres. Las tres damas francesas aluden en sus nombres al escudo de armas de los reyes de Francia: bello armiño (Belarminia), del'Azur (Deleasir), la flor de lis (Felix Flora) ${ }^{11}$ El duque de Nemurs lo ayuda a ubicar los episodios de los capítulos 13-15 en torno al edicto firmado por Enrique III en Nemurs, en 1585, donde se revocaba la tolerancia concedida a los protestantes, cediendo así a las exigencias de la Santa Liga. En el bando católico militaba la casa de Guisa, una de cuyas ramas era la casa de Lorena. Enrique III, muerto a cuchillo, muchas veces caricaturizado como un Nerón (Domicio es el segundo nombre de Nerón), favorecía a los hugonotes. Francia no estaba tan pacífica como se anuncia al entrar (III, 12, 564).

Nevoux, que reconoce algunos nombres franciscanos (Clara, Antonio), también nos sorprende con una asociación feliz, que opone al clima de confrontación el de fiesta: se trata de la asociación de Claricia a la Infanta Isabel Clara Eugenia, hija de Felipe II e Isabel de Valois. Interesante, porque la interpretación franciscanista, en ella que convierte la torre en iglesia- queda asociada a la política. Sucede que Felipe II hubiera querido convertir a Isabel Clara Eugenia en reina de Francia, bodas mediante. Nacida el día de Santa Clara, terciaria franciscana, vestía su hábito y visitaba el Real Monasterio de las Descalzas Reales, donde residían su tía y su prima. Ésta sería la enigmática "casi real casa" a la que se dirige la comitiva después del trágico pero triunfante episodio de la torre. ${ }^{12}$

En el episodio de Antonio y Félix Flora, versión del mito del rapto de Europa, Nevoux reconoce una de las arquitecturas efímeras que habían acompañado a Isabel de Valois

11 Nevoux reconoce su deuda con Nerlich (2005: 495-505) en la interpretación de los nombres.

12 Ver la interpretación del episodio de la torre de Cecilio Peña (2020: 107). 
en su entrada en Toledo para casarse con Felipe II. Retoma la interpretación de André Lubac, quien observa que hay una boda franco-española en las primeras obras de Cervantes, los sonetos escritos a la muerte de Isabel de Valois, y en la obra póstuma, ésta, el Persiles, en cuyo final también un español se casa con una francesa: se trata de Antonio y Felix Flora.

Por estas asociaciones, el cuerpo místico, representado por los peregrinantes, recibe en el camino francés las connotaciones que surgen del valor y el sacrificio en la defensa de la fe y del amor de Creación que propone la ascética gozosa de la espiritualidad franciscana. No solo el grupo de peregrinos. En esta lectura que va de la Historia a la Poesía (y no al revés), la figura de Carlos V, que articula imperio y retiro para el rey dimitente, se tiñe, por contagio de la peculiaridad del contexto francés de todos los valores connotados. Lo que nos interesa es subrayar cómo por los nombres que dicen historia, hemos accedido sutilmente a la autobiografía íntima del autor (mucho más que por los cliché de circunstancias biográficas evocadas en otros episodios, como el del falso lienzo de II, 10).

\section{En España}

Volvemos al curso novelesco. Sin duda, Carlos V, repetidamente nombrado en el contexto del eremitismo, coloca la grandeza del rey en su renunciamiento, que recibe, en contacto con los franceses, acentos franciscanos.

Pero es en España donde se articula la sustitución novelesca más importante. No hay historia referenciada por los nombres. La narración misma opera la alteración. Tampoco hay realeza, pero se trata del lugar capital. Sucede en el paso de la peregrinación por Quintanar de la Orden (III, 9). Allí la novela experimenta un cambio de roles verdaderamente decisivo. Si bien Antonio padre anuncia repetidamente la llegada a su patria, cuando ésta finalmente se produce, el novelista frustra el esperado patetismo de la anagnórisis. Más que exclamativos reconocimientos, seguidos de conmovidos abrazos, asistimos a un testeo racionalizado por parte de Antonio de la eventual recepción de sus padres. Luego de tomar el fresco pueblerinamente a las puertas de su casa-merece notarse esta escena anticlimática-, casi sin solución de continuidad, se precipitan, no sobre su pródigo hijo, sino en el auxilio de un conde herido a cuchillo en una revuelta popular (similar arma que hiere a Periandro, en Provenza). Muchos parentescos se cruzan a partir de este momento en la vivienda del anciano Villaseñor: hijos, nietos, tías, tíos, abuelos: una familia de bárbaros y españoles.

Resultado: Antonio el viejo abandona la novela. Con la disolución del conflicto de la honra, hasta su mismo exilio parece incongruente. Su propio padre se convierte en portador del rol de Padre. Éste, a su vez, lo transfiere al nieto, Antonio el joven. La verdadera Presentación ante el Padre está a cargo de su hijo Antonio, el bárbaro español, quien toma a su cargo la lectura del lienzo con toda la historia ocurrida a los peregrinantes, figura del corpus mysticum. Nueva hipóstasis del relato de la historia de los peregrinos, que será recordada por mucho tiempo porque quedará grabada en láminas de bronce. Por alguna razón, el relato del lienzo se completa con el de Auristela.

En sintonía con esta alteración de la sucesión del lugar capital, Ricla también abandona la novela. No habrá desorden en la sucesión femenina. Deja su función de tesorera, administradora de los lingotes bárbaros, a su propia hija, Costanza, semi-bárbara, quien, por casamiento con el conde, alcanzará mayor dignidad que la que hubiera recibido de su abuelo. También administrará riqueza. Viuda y heredera, será "señora del universo", según palabras del mismo conde asesinado (IV, 3, 521). 
Kantorowicz explica la constitución del rex sacerdos por la analogía con la doble naturaleza de Cristo y por la posterior extensión de este concepto al Corpus-christi. De manera semejante, entendemos que Cervantes está trabajando con alegorías. Desde la perspectiva de la sustitución de un rey por otro, deberíamos tener en cuenta que en el registro natural del estilo (al que se suman todos los significantes de lo propio: España, la honra, la figura patriarcal), subrepticiamente se cuela una alteración. Si recordamos ahora el linaje diverso es que también la sucesión en la familia Villaseñor hay una alteración. Casi inadvertida, como un estremecimiento narrativo, la sustitución de Antonio por su hijo, de ascendencia contaminada, delata la incidencia de lo extraordinario en lo natural.

En suma: España sirve para novelar la constitución sagrada del corpus mysticum. Francia la coloca en la historia, que transparenta su más sentida autobiografía.

No es de estirpe real la familia que se reúne en Quintanar de la Orden, pero en este contexto de asociaciones, apuntamos la posible circulación subrepticia de una alusión a Carlos V en la fundante España. Inevitable registrar, al menos como sugerencia, la homologación Quintanar de la Orden / San Quintín. La famosa victoria de España en 1557, en territorio francés, dio lugar a que Felipe II, rey anticipadamente, hiciera construir el Escorial, palacio-monasterio que había de servirle de mausoleo a su padre, Carlos V. ${ }^{13}$

\section{La alteración}

El modelo de la alteración del linaje, novelado en la llegada de Antonio a su "patria", está inscripto en la novela desde el principio, aunque en cifra invertida. Pienso en la profecía de los bárbaros (I, 2), que supone la extracción del corazón animoso de un héroe sacrificado, su pulverización y posterior ingesta, en forma de brebaje, por parte de los postulantes a rey. No el que lo trague sin hacer visajes -esto es, como si fuera connatural a él-, sino su hijo, sería el conquistador del mundo.

Quiere decir que el corazón del héroe no bárbaro, una vez sacrificado, y convertido en alimento, renovaría un linaje otro, el bárbaro. Sólo a partir del sacrificio comienza el traspaso generacional. Pero también la estirpe beneficiada debe superar una prueba: hay un padre que debe demostrar la capacidad de asimilar el alimento cordial para que la virtud heroica reencarne en su hijo, destinado a expandirla en el universo todo.

El sacrificio, el valor sobre-natural, traspasado de padre a hijo, el corazón, la ingestión, la expansión a todo el orbe: el autor parece hablar de la comunicación del Corpus Christi al Corpus mysticum, la Iglesia, por la participación en la Eucaristía.

La profecía bárbara concentra la novela entera. Desde el corazón al cadáver. En las imágenes de las dos ermitas de Renato y Eusebia vimos representado en imágenes el episodio que consagró esta alianza. Los sucesos ocurridos en Francia muestran la expansión renovadora del espíritu (con marcas franciscanas, en medio de enfrentamientos). A su vez, la cita de las Confesiones (I, 1), que aparece y se esconde en el recorrido novelesco, nos habla de este apasionado corazón heroico que vive en el curso de la historia: “...porque nos criaste para vos, está inquieto nuestro corazón hasta que descanse en Vos". ${ }^{14}$

13 El Escorial está lejanamente evocado en el autor de “versos” Juan de Herrera de Gamboa, ya que Juan de Herrera fue su arquitecto y Juan de Gamboa, el ebanista de la biblioteca y el coro (III, 2, 446). 


\section{Maximino}

Hemos contrastado a Maximino con algunos monarcas similares, sugeridos o cabalmente citados. Si ahora nos colocamos junto con Rutilio para oír la revelación de la historia de Maximino de boca de Serafido, notamos que nuestros modelos especulares -Carlos V, San Pedro- carecen de una nota que comparte con su hermano, Persiles: el amor a Auristela. La novela, sin embargo, nos ofrece otros enamorados por los que ha circulado subrepticiamente el apasionado Príncipe Maximino: allí está la flecha del bárbaro gobernador que acaba con el deseo de Bradamiro de poseer a Auristela, a su vez vengado por el hijo de Corsicurvo, autor de "voces" en el mítico principio novelesco (I, 4); también el deseo mal colocado del viejo rey Policarpo, quien olvida que él es la cabeza, quizás porque fue elegido rey por el cuerpo ${ }^{15}$ o el perpetuo gemelo antagónico, el príncipe Arnaldo, espiritualizante enamorado de un retrato, al punto que llega a abandonar a su amada por acudir a su padre enfermo, al que se sujeta hasta el último renglón de la novela sin atreverse a sucederlo. ${ }^{16}$

Pero, si bien hemos encontrado paralelos del Príncipe Maximino en otros reyes, no existe en toda la narración ningún desdichado personaje a quien su madre haya postergado en favor de su hermano menor, en este caso para curarlo de su enfermedad amorosa. Debemos buscar un punto de referencia fuera de la novela. Y lo encontramos dentro de los parámetros del arquetipo vecino, el del hermano mayor. Estamos pensando en el modelo que provee el Génesis ( 25 y 27), la suplantación del heredero de Isaac, Esaú, por Jacob, su hermano menor, gracias a una estratagema urdida por la madre, Rebeca. ${ }^{17}$ La idea de suplantar las apariencias, y quizás la prenda ofrecida, un cabrito asado, llevó a la tradición, que recoge Villegas (1591: 62), a reconocer en este relato del Antiguo Testamento, una prefiguración de la transubstanciación eucarística, tal como se celebra en la fiesta de Corpus Christi.

Por eso es importante tener en cuenta que la última imagen de Maximino en la novela, no es ni la del apasionado, ni la del guerrero, ni la del sacerdote que "ata y desata", sino la de su cadáver. Maximino no es un rey que se retira a meditar. Cuando se entera de la ausencia de Sigismunda, parte a buscarla con "gruesísimas naves", entra en el Mediterráneo por el "estrecho hercúleo"-no por Lisboa como el resto de los personajes, hace notar Marculescu (2004)-, con lo que devuelve a la novela el paisaje de los mares nórdicos, pero la fuerza hercúlea parece abandonarlo. El trayecto hasta Roma lo "muta", y muere. Volvemos a las escenas con que comenzamos el trabajo.

En ese contexto, asociamos la enfermedad de la "mutación" no sólo a la conversión de San Pablo, sino, en línea con la sugerencia a la que nos atrevimos antes: la suplantación de hermanos como prefiguración eucarística, al concepto del Christus passus. ${ }^{18}$ Trasladado a la Basílica de San Pablo, adquiere una dimensión eclesial. Corpus Christi-corpus mysticum. ${ }^{19}$ El cuerpo de Cristo, por participación de la cabeza en el cuerpo (Efesios, 5, 27), se convierte en el cuerpo místico de la Iglesia. La novela

15 Recordemos que Policarpo, como todos los reyes de su isla, había sido elegido por el pueblo (el cuerpo, en la analogía paulina).

16En el largo relato de Periandro (II), existen dos reyes más, que no entran en la casuística de la sucesión o retiro del poder. Ambos, de estilo novela a la bizantina. En el capítulo 13 del libro II, aparece Leopoldio, rey de los dáneos, cuya vejación repara Periandro. Viudo, enamorado desacertadamente, como Policarpo, su suerte se relata justo sobre la isla gobernada por este rey (tampoco un caso de sucesión, sino de pasión). Cratilo, rey de Bituania, tío de Sulpicia, presentado por ella antes del "sueño", resulta un vehículo para armonizar la clásica alegoría platónica con el cristianismo, ya en tierra de salvación (ut supra).

17 Diana de Armas Wilson también establece una analogía entre los hermanos bíblicos y Maximino y Persiles.

18 La idea de "mutación” recibe una interesante interpretación en el trabajo de Juan Diego Vila (2020), inédito.

19Segunda autolimitación divina, la Eucaristía se compara con el Sacrificio de la Cruz por la relación de visibilidadinvisibilidad. En el Himno eucarístico Pange Lingua, Santo Tomás adora al "Dios escondido": "En la cruz se escondía solo la Divinidad, pero aquí se esconde también la Humanidad". 
parece cumplir la profecía de los bárbaros. El corazón, transformado en alimento connatural, comunica sus valores a todo el cuerpo, y le confiere unidad a lo largo de la historia. ${ }^{20}$

La Basílica de San Pablo se nos presenta, así, en la novela como el punto de convergencia, no sólo de la peregrinación sino de todas las coordenadas de sentido que articulan el Persiles como artificio poético, desde la peregrinación de gentiles, la renovación de los tiempos que la estructuran, la imagen del rey, el casamiento de Cristo con la Iglesia... Vacía de imágenes, como las que exhiben otras construcciones eclesiales -las ermitas o el monasterio de Guadalupe-, la basílica que corona el Persiles parece reservar el espacio para las escrituras de Pablo sobre las que se articula el curso novelesco. ${ }^{21}$ Una última cita nos llevará a la poética de la memoria. Leemos en 1 Corintios la que es la primera narración de la Institución de la Eucaristía:

El Señor Jesús, la noche en que fue entregado, tomó pan, dio gracias, lo partió y dijo: "Este es mi Cuerpo, que se entrega por ustedes. Hagan esto en memoria mía". De la misma manera, después de cenar, tomó la copa, diciendo: "Esta es la copa de la Nueva Alianza que se sella con mi Sangre. Siempre que la beban, háganlo en memoria mía. Y así, siempre que coman este pan y beban esta copa, proclamarán la vuelta del señor hasta que Él vuelva" (1 Corintios, 11, 23-26).

En la liturgia cristiana, las palabras de Cristo que repite Pablo operan la transubstanciación de especies. Por eso, el Christus passus, el Cristo inmolado, está en el centro del sacramento "por antonomasia". Así dice santo Tomás: "La Eucaristía es el sacramento de la pasión del Señor, ya que contiene al propio Cristo que padeció" (Suma LXXIII, art.2 ad 3m) $)^{22}$. Por ser "de época", citamos este texto del Concilio de Trento, que a su vez contiene tres citas de san Pablo (con la inclusión de Melquisedec, cuyos dones, además, pasaron a prefigurar los eucarísticos) y la tradicional alegoría de la Iglesia como Esposa de Cristo ${ }^{23}$ :

(Cristo), nuestro Dios y Señor [...] se ofreció a Dios Padre [...] una vez por todas, muriendo como intercesor sobre el altar de la cruz, a fin de realizar para ellos (los hombres) una redención eterna. Sin embargo, como su muerte no debía poner fin a su sacerdocio ( $\mathrm{Hb} 7,24-27)$, en la última Cena, "la noche en que fue entregado" (I Co 11, 23), quiso dejar a la Iglesia, su esposa amada, un sacrificio visible (como lo reclama la naturaleza humana) [...] donde sería representado el sacrificio sangriento que iba a realizarse por única vez en la cruz, cuya memoria se perpetuaría hasta el fin de los siglos (I Co 11, 23) y cuya virtud saludable se aplicaría a la redención de los pecados que cometemos cada día (Concilio de Trento: DS 1740).

El texto cervantino da por muertos a los dos hermanos. También a Persiles: “En efeto, frontero del templo de San Pablo, en mitad de la campaña rasa, la fea muerte salió

20Descartamos la tradición medieval del “corazón comido" como antecedente de la profecía. Armstrong-Roche (2009: 41-42) y notas, aborda el motivo del canibalismo de Historias de Indias desde el marco de la doctrina tridentina de la Transubstanciación. Isabel Lozano Renieblas (1998: 138-140) no cree que Cervantes esté en deuda directa con estas reediciones del motivo. Ambos críticos remiten al Motif Index de Stith Thompson, Q.478.1

21 Creo que es importante notar que en el párrafo anterior a la llegada a la "iglesia y templo magnífico" de San Pablo, el autor nos presenta el monasterio de Santo Tomás en Groenlandia. Desde allí monjes de cuatro naciones enseñan sus lenguas para que los habitantes de la isla fueran entendidos “do quiera que fueren". La asociación con la Fiesta de las Naciones, Pentecostés, y el don de lenguas paulino (I. Cor 12,8, casi inmediatamente a continuación de la cita "eucarística") es inevitable. Nos preguntamos si la sugerencia se extiende al valor simbólico de la peregrinación. Salvo Sorin Marculescu (2004), la crítica ha prestado poca atención al monasterio tomista.

22 Cita tomada de Vonier, Dom Ascario, 1946, 138.

2314 Aparte de textos doctrinarios, las Crucifixiones y Custodias de la época pueden atestiguar la importancia dada tanto al cuerpo inmolado como a su ocultamiento en la Eucaristía. Recordemos que Cervantes, antes de ordenarse en la tercera orden de San francisco, perteneció a la Orden del Santísimo Sacramento (Canavaggio, 1986). La relación entre Eucaristía e imagen data de las reflexiones de los Padres, a propósito de las primeras controversias entre iconoclastas e iconófilos (Sáenz, 1991: 75-77) 
al encuentro al gallardo Persiles" (IV, 14, 711). Y es él quien deposita a Maximino en San Pablo (IV, 14, 713). De modo que las dos escenas finales de la novela, de las que partimos en estas reflexiones, contiguas pero separadas por el corte de capítulo, unidas por la sangre pero disímiles en el estilo, estarían alegorizando el acontecimiento fundante (el sacrificio de la Cruz) y su actualización eclesial (la Eucaristía). Persiles y Maximino son figuras alegóricas de Cristo y su Vicario.

\section{Colofón}

Todo texto es autorreferencial. Y más, uno tan manierista como el Persiles. El nombre Maximino se alinea con otros nombres cervantinos que indican homogeneidad entre principio y fin. Sugestivamente, son nombres de "autores". Así, las voces de Corsicurvo que abren el Persiles, generan en la novela la vida del personaje protagónico; don Quijote imagina en boca del gigante Caraculiambro el primer texto incluido en el Quijote, que es, además, texto de nombres. Podemos pensar que el moribundo Maximino nos reenvía, traspasando niveles de realidad, al moribundo autor de la novela (enterrado con el hábito de la Tercera Orden de San Francisco). Antepone a ella, una sentida "Dedicatoria a don Pedro Fernández de Castro", figura real cuya presencia sin embargo solo puede anticipar en profecía, y un Prólogo que es pura representación grotesca. Si bien renuncia, en las proximidades de la muerte, a la musa de otras épocas, el encuentro con el estudiante pardal reedita los regocijados encuentros de camino del Quijote. Desde estas contradictorias páginas fuera de los muros del libro, el autor nos entrega sus Trabajosa modo de sustento que une en regocijo tiempos de vida y tiempos de muerte. ${ }^{24}$

24La alegoría eucarística como poética es una constante en el Quijote, donde no sólo hay cadáveres de poetas, sino nombres de Padres de la Iglesia o de la filosofía tomista. Véanse, o en Seminario sobre el 'Quijote' las páginas dedicadas a las poéticas de la Parte I, o al episodio de los duques en la Parte II, pp.113-125 y 171-183. Son solo algunos ejemplos: todo el Quijote puede ser entendido desde la ecuación libro / Eucaristía, ambos objetos con escasa exterioridad y un altísimo valor que irradian más allá de sus límites. En línea con la exégesis paulina, ver el comentario al Prólogo de Clea Gerber (2018). Véase también, de María de los Ángeles González Briz, “Escritos póstumos: lo que viene después" (2020). 


\section{Q Bibliografía}

》Armstrong-Roche, M. (2009). Cervantes'Epic Novel, Empire, Religion and the Dream Life of Heroes in 'Persiles'. Toronto: University of Toronto Press

"Cervantes, M. de (2004). Los trabajos de Persiles y Sigismunda, ed. de Carlos Romero Muñoz. Madrid: Cátedra.

" Canavaggio, J. (1986). Cervantes. Madrid: Espasa-Calpe.

»Colahan, C. (2019). "El Cratilo cervantino, rey septentrional y criado real de Vandalucía”, en Hipogrifo, Vol. 7, nº 1, 49-58.

»De Certeau, M. (1993). La fábula mística. Siglos XVI-XVII. México: Universidad Iberoamericana.

»De la Vorágine, S. (1995). La leyenda dorada. Madrid: Alianza Editorial.

»El Libro del pueblo de Dios, La Biblia (1981). Buenos, Aires: Paulinas.

"Catecismo de la Iglesia católica (1993). Bilbao: Asociación de editores del Catecismo.

"Forcione, A. K. (1972). Cervantes Christian Romance. Princeton: Princeton University Press.

» Gerber, C. (2018). “'Que yo me voy muriendo': temporalidad, viaje y amistad en los Preliminares del Persiles de Cervantes", Hipogrifo. Revista de literatura u cultura del Siglo de Oro, V.6, 3, 9-11.

"González Briz, M. de los A., (2020). "Escritos póstumos: Lo que viene después", en su El último mundo cervantino. Miradas desde el sur. Montevideo: CSIC Universidad de la República, Biblioteca Plural, 149-161.

»Guénon, R. (1985). El rey del mundo. Buenos Aires: Fraternidad.

» Henry, M. (2001). Encarnación. Salamanca: Sígueme.

» Kantorowicz, E. (1985). Los dos cuerpos del rey. Un estudio de teología política medieval. Madrid: Alianza.

»Leuker, T. (2011). "Exaltación y relativización de la vida solitaria en el Persiles de Cervantes", en Ortodoxia y heterodoxia en Cervantes, ed. de Carmen Rivero Iglesias. Alcalá de Henares: Centro de Estudios Cervantinos, 83-95.

»Lozano Renieblas, I. (1998). Cervantes y el mundo del Persiles. Alcalá de Henares: Centro de Estudios Cervantinos.

»Marculescu, S. (2004). “El paso por Lisboa: el mundo del Persiles como un reloj de arena, en Peregrinamente peregrinos, ed. de Alicia Villar Lecumberri. Alcalá de Henares: Asociación de Cervantistas, I, 523-530.

»Nerlich, M. (2005). El 'Persiles' decodificado o la “Divina Comedia” de Cervantes. Madrid: Hiperión.

»Nevoux, P. (2016). “Recrear (con) la Historia la reescritura lúdica de la historia francesa en el Persiles III, 13-15", en "'Si por atrevido no sale con las manos en la cabeza': el legado poético del Persiles cuatrocientos años después”. EHumanista/Cervantes, 6, 387-418.

»Panofsky, E. (1984), Idea. Madrid: Cátedra. 
"Parodi, A. (2017). Seminario sobre el 'Quijote'. Buenos Aires: Eudeba.

» Parodi, A. (2018 a). "Sobre la alegoría en el Persiles. A propósito de las claves propuestas por Cecilio Peña”, en El último mundo cervantino (Miradas desde el Sur), coord. por María de los Ángeles González Briz, Montevideo, CSICUniversidad de la República, Biblioteca Plural, 95-134.

»Parodi, A. (2018 b). “Antonio y el rex en la revolución solar del 'Persiles”. En Don Quijote en Azul 10, coord. por Julia D’Onofrio, Clea Gerber y Noelia Vitali. Tandil: Unicen, 195-109

» Patch, H.R., (1956), El otro mundo en la literatura medieval. México, Fondo de Cultura Económica.

"Peña, C. (2020). “Una aproximación en el Persiles”. En El último mundo cervantino (miradas desde el sur), coord. por María de los Ángeles González Briz. Montevideo: CSIC- Universidad de la República, Biblioteca Plural, 93-134.

»Réau, L., (1996). Iconografía del arte cristiano. Iconografía de la Biblia. Nuevo testamento (1996). Barcelona: Ediciones del Serbal.

"Sáenz, A. (1991). El ícono, esplendor de lo sagrado. Buenos Aires: Gladius.

"San Agustín (1941). Confesiones. Buenos Aires: Poblet.

»Villegas, Alonso de (1591). Flos sanctorum, Toledo.

»Vorágine, Santiago de (1995). Leyenda áurea Madrid: Alianza.

»Vila, J.D. (2020). “'Qué haremos después que una misma coyunda nos ate y un mismo yugo oprima nuestros cuellos'. Coordenadas mesiánicas del Libro IV del Persiles' (inédito).

"Vonier, D. A. (1946). Doctrina y clave de la Eucaristía. Buenos Aires: Emecé.

»Wilson, D. de A. (1991). Allegories of Love: Cervantes' Persiles and Sigismunda. Princeton: Princeton U.P. 
